\title{
PENGARUH RETURN ON ASSETS, DEBT TO EQUITY RATIO DAN PRICE TO BOOK VALUE TERHADAP RETURN SAHAM PERUSAHAAN LQ45 TERDAFTAR DI BURSA EFEK INDONESIA PERIODE 2016 - 2018
}

\author{
Eka Putra Jaya \\ Sekolah Tinggi Ilmu Ekonomi Wiyatamandala \\ pj.eka2090@gmail.com \\ Randy Kuswanto \\ Sekolah Tinggi Ilmu Ekonomi Wiyatamandala \\ randy@wym.ac.id
}

\begin{abstract}
This research was conducted to examine the effect of Return on Assets, Debt to Equity Ratio and Price to Book Value on LQ45 Company's stock returns listed on the Indonesia Stock Exchange in the period of 2016 - 2018. Data collection techniques used were documentation using secondary data. The data analysis method used is a quantitative method with associative and descriptive method approaches. The analysis technique used is multiple regression and hypothesis testing using partial $t$-test and $F$ test simultaneously with a significance level of $5 \%$. The results showed that Return on Assets had a negative and significant effect on stock returns with a significance value of 0,000 and had a $t$-value of -4.176 (greater than t table-1.98447). Price to Book Value has a positive and significant effect on stock returns with a significance value of 0.010 and a $t$ value of 2.623. All independent variables simultaneously proved to have a significant effect on stock returns with a significance value of 0.001 .
\end{abstract}

Keywords: Return on Assets, Debt to Equity Ratio, Price to Book Value, Stock Return

\begin{abstract}
ABSTRAK
Penelitian ini dilakukan untuk menguji pengaruh return on assets, debt to equity ratio dan price to book value terhadap return saham perusahaan LQ45 terdaftar di Bursa Efek Indonesia periode 2016-2018. Teknik pengumpulan data yang digunakan adalah dokumentasi dengan menggunakan data sekunder. Metode analisis data yang digunakan adalah metode kuantitatif dengan pendekatan metode asosiatif dan deskriptif. Teknik analisis yang digunakan adalah regresi berganda dan uji hipotesis menggunakan uji-t secara parsial dan uji $\mathrm{F}$ secara simultan dengan level signifikansi 5\%. Hasil penelitian menunjukan return on asset berpengaruh negatif dan signifikan terhadap return saham dengan nilai signifikansi 0,000 dan memiliki nilai t hitung -4,176 (lebih besar dari t tabel 1,98447). Price to book value berpengaruh positif dan signifikan terhadap return saham dengan nilai signifikansi 0,010 dan nilai t hitung 2,623 . Seluruh variabel independen secara simultan terbukti berpengaruh signifikan terhadap return saham dengan nilai signifikansi 0.001 .
\end{abstract}

Kata Kunci : Return on Assets, Debt to Equity Ratio, Price to Book Value, Return Saham 


\section{PENDAHULUAN}

Tujuan utama investor atau penanam modal memilih alternatif investasi adalah mendapatkan return yang paling menguntungkan atau optimal. Return tersebut dijadikan sebagai alat ukur untuk menilai seberapa besar keuntungan suatu investasi. Salah satu produk sekuritas yang biasa diperjualbelikan di pasar modal adalah saham. Investor yang memilih alternatif investasi saham tentunya mengharapkan return saham yang paling besar. Menurut (Fahmi, 2013) return saham merupakan profit atau keuntungan yang diperoleh perusahaan, individu dan institusi dari hasil kegiatan investasi yang dilakukannya. Sumber-sumber return saham menurut (Hartono, 2016) ada dua, yaitu capital gain (accrual return) dan yield. Capital gain merupakan hasil yang diperoleh dari selisih harga pembelian atau dalam hal ini adalah kurs beli dengan harga penjualan dengan kata lain adalah kurs jual. Melihat hal tersebut capital gain terjadi jika adanya selisih antara kurs beli dan kurs jual. Yield adalah persentase penerimaan kas periodik terhadap harga investasi periode tertentu dari suatu investasi. Melihat hal tersebut, yield pada saham merupakan persentase dividen terhadap harga saham periode sebelumnya. Menurut (Hartono, 2013) terdapat dua jenis return saham, yaitu realized return dan expected return. Realized return atau return realisasi adalah return yang sudah terjadi (sudah diterima oleh investor). Realized return penting karena digunakan sebagai salah satu pengukur kinerja dari perusahaan. Realized return disebut juga return historis juga berguna sebagai dasar penentuan expected return. Expected return merupakan return yang diharapkan akan diterima atau diperoleh investor di masa mendatang. Berbeda dengan return realisasi yang sifatnya sudah terjadi, expected return sifatnya belum terjadi. Para investor sebelum berinvestasi di pasar modal terlebih dahulu menilai kinerja perusahaan agar mendapatkan return atau keuntungan yang paling tinggi, khususnya kinerja dalam hal kondisi keuangan perusahaan. Semua investor tentunya akan memilih perusahaan yang mempunyai kondisi 
keuangan yang baik, karena kondisi keuangan perusahaan tersebut akan mempengaruhi harga saham di pasar. Investor tidak hanya melihat kondisi keuangan perusahaan saat ini tetapi juga akan menganalisis prospeknya di masa mendatang. Kondisi keuangan perusahaan yang baik akan memiliki pengaruh pada peningkatan harga saham dan tentunya setiap investor memiliki harapan jika return sahamnya pun dapat meningkat. Di bawah ini merupakan kinerja return IHSG saham di Bursa Efek Indonesia periode 2014-2018 :

Tabel 1 Kinerja Return IHSG saham di Bursa Efek Indonesia periode 2014-2018

\begin{tabular}{|c|c|c|c|c|c|}
\hline Tahun & 2014 & 2015 & 2016 & 2017 & 2018 \\
\hline Return (\%) & $-4,46$ & 20,32 & $-12,64$ & 9,66 & 9,13 \\
\hline
\end{tabular}

Sumber: data yang diolah (2019)

Dari tabel tersebut kita dapat melihat pergerakan return saham LQ45 yang dimulai dari tahun 2014 hingga tahun 2018 bergerak secara fluktuatif. Puncak tertinggi dari periode 2014 2018 terjadi pada tahun 2015 sebesar $20,32 \%$ dan puncak terendahnya pada tahun 2016 sebesar -12,64\%. Melihat dari tersebut dapat disimpulkan jika pergerakan return saham dapat mengalami kenaikan bahkan penurunan yang drastis. Kenaikan dan penurunan yang drastis membuat para investor harus mengetahui faktor-faktor yang mempengaruhi return saham agar tidak terjadi kesalahan dalam pengambilan keputusan. (Samsul, 2015) berpendapat terdapat banyak faktor yang mempengaruhi return saham dan harga saham, ada yang bersifat faktor mikro maupun makro ekonomi. Menurutnya faktor makro tersebut ada yang bersifat ekonomi dan juga nonekonomi. Variabel ekonomi seperti suku bunga, kurs, valuta asing, inflasi, harga bahan bakar minyak di pasar internasional dan indeks regional termasuk dalam faktor makro ekonomi. Sedangkan peristiwa hukum, peristiwa politik domestik maupun peristiwa politik internasional termasuk faktor makro non ekonomi. Dalam penelitian ini 
faktor mikro ekonominya yaitu return on assets, debt to equity ratio dan price to book value. Return on assets menunjukan seberapa efektif perusahaan dalam memanfaatkan asetnya. Semakin meningkatnya ROA maka profitabilitas perusahaan semakin baik sehingga akan menaikan harga saham sekaligus akan mempengaruhi return saham. Price to book value menunjukan seberapa tinggi suatu saham perusahaan tersebut. Semakin kecil PBV maka harga saham perusahaan tersebut dianggap semakin murah sehingga akan mempengaruhi return saham. Debt to equity ratio digunakan untuk mengukur tingkat leverage dalam menunjukan kemampuan perusahaan untuk memenuhi kewajiban jangka panjang. Debt to equity ratio yang tinggi menunjukan liabilitas perusahaan lebih tinggi dari ekuitas perusahaan tersebut yang mencerminkan resiko perusahaan yang relatif tinggi. Resiko yang relatif tinggi akan menurunkan daya tarik investor, sehingga berpengaruh terhadap penurunan harga saham yang berakibat terhadap total return saham. Penelitian yang dilakukan
(Nasrullah, 2011) menunjukan ROA berpengaruh terhadap return saham tetapi penelitian yang dilakukan oleh (Hadi, 2012) ROA tidak berpengaruh terhadap return saham. DER yang diteliti oleh (Prihantini, 2009) berpengaruh negatif terhadap return saham sedangkan DER yang diteliti oleh (Fadhilah Fitri, 2018) tidak berpengaruh terhadap return saham. Melihat adanya perbedaan tersebut penulis ingin melakukan penelitian kembali agar dapat menyimpulkan beberapa variabel yang mempengaruhi return saham melalui penelitian yang berjudul "Pengaruh Return on Assets, Debt to Equity Ratio dan Price to Book Value Terhadap Return Saham Perusahaan LQ45 Terdaftar di Bursa Efek Indonesia Periode 2016 - 2018". Perumusan masalah antara lain sebagai berikut:

- Apakah return on assets berpengaruh terhadap return saham perusahaan LQ45?

- Apakah debt to equity ratio berpengaruh terhadap return saham perusahaan LQ45? 
- Apakah price to book value saham perusahaan LQ45? berpengaruh terhadap return

\section{TELAAH LITERATUR}

Pengertian Pasar Modal

Menurut (Fahmi, 2015) pasar modal adalah tempat dimana berbagai pihak khususnya menjual saham dan obligasi dengan tujuan dari hasil penjualan tersebut nantinya akan digunakan sebagai tambahan dana atau untuk memperkuat modal perusahaan. Undang-Undang No.8 Tahun 1995 mengenai Pasar Modal mendefinisikan pasar modal merupakan segala kegiatan yang berhubungan dengan penawaran umum maupun perdagangan ekuitas, perusahaan publik yang berhubungan dengan ekuitas yang diterbitkan serta lembaga dan profesi yang berkaitan dengan ekuitas atau efek. (Sudrajat, 2015) berpendapat pasar modal berperan dalam menunjang pelaksanaan pembangunan nasional dalam rangka meningkatkan pemerataan, pertumbuhan dan stabilitas ekonomi nasional kearah peningkatan kesejahteraan rakyat. Sekuritas yang biasanya diperjualbelikan yaitu saham, reksadana, obligasi, dan instrument derivative.

Pengertian Laporan Keuangan (Kasmir, 2013) berpendapat laporan keuangan merupakan laporan yang menunjukan kondisi keuangan perusahaan pada saat ini atau dalam suatu periode tertentu. (Jumingan, 2011) mengenai Analisis Laporan Keuangan bahwa laporan keuangan terdiri dari neraca, laporan laba rugi, laporan laba yang ditahan dan laporan modal sendiri. Berdasarkan (Ikatan Akuntansi Indonesia, 2012) laporan keuangan adalah suatu penyajian laporan yang terstruktur dari posisi keuangan dan kinerja keuangan suatu perusahaan yang terdiri dari neraca, laporan laba rugi, laporan perubahan posisi keuangan, laporan arus kas dan catatan atas laporan keuangan dimana masingmasing laporan keuangan ini berisi akun-akun yang saling terhubung. Menurut (Verawati Rika, 2014) untuk mengetahui kesehatan keuangan dan perkembangan perusahaan setiap kali laporan 
keuangan diterbitkan maka diperlukannya analisis rasio dan analisis tren. Analisis rasio keuangan merupakan membandingkan antara unsur-unsur neraca, unsur-unsur laba rugi serta rasio keuangan emiten yang satu dengan rasio keuangan emiten lainnya.

Jenis - jenis laporan

keuangan menurut (Kasmir, 2013) dalam praktiknya secara umum ada lima macam jenis laporan keuangan yaitu neraca, laporan laba rugi, laporan perubahan modal, laporan arus kas dan laporan catatan atas laporan keuangan.

\section{Pengertian Saham}

Saham menurut (Verawati Rika, 2014) adalah suatu bukti kepemilikan atas aset-aset perusahaan yang menerbitkan saham. Jadi, dalam saham ada tanda penyertaan dalam suatu perusahaan. Menurut (Widoatmodjo, 2012) dengan menyertakan modal tersebut maka pemilik atau pemegang saham berhak atas pendapatan perusahaan, aset perusahaan dan memiliki hak untuk ikut serta dalam Rapat Umum Pemegang Saham (RUPS). Saham merupakan selembar kertas yang menunjukan hak yang memegang saham tersebut yaitu pemodal atau pemilik kertas tersebut untuk mendapatkan bagian dari prospek maupun kekayaan organisasi yang menerbitkan sekuritas tersebut. Saham yang biasa diperjualbelikan di Bursa Efek Indonesia :

\section{Common Stock atau Saham Biasa} (Hadi, 2013)mengatakan bahwa pemegang saham biasa ditempatkan paling akhir dalam hal claim. Pemegang saham biasa memiliki suara dalam Rapat Umum Pemegang Saham (RUPS).

2. Preferred Stock atau Saham Preferen

Hartono (2010) berpendapat jika saham preferen memiliki hak dividen, hak dividen kumulatif dan memiliki hak terlebih dahulu atas aktiva perusahaan dibanding hak yang dimiliki oleh pemegang saham biasa ketika terjadi likuidasi.

Pengertian Return Saham

(Hadi, 2013) berpendapat return saham merupakan tingkat keuntungan yang dinikmati oleh 
pemodal atas suatu investasi yang dilakukannya. (Verawati Rika, 2014) berpendapat return adalah hasil yang didapat dari investasi sedangkan saham adalah tanda bukti kepemilikan dalam suatu perusahaan yang berbentuk Perseroan Terbatas. Return saham itu berarti pembayaran yang diterima karena hak kepemilikannya yang diperoleh dari harga perubahan pada harga pasar dibagi dengan harga awal. Komponen return saham terdiri dari dua jenis yaitu pendapatan lancar (current income) dan keuntungan selisih harga. (Verawati Rika, 2014) menyatakan pendapatan lancar merupakan keuntungan yang didapatkan dari pembayaran yang bersifat periode seperti pembayaran bunga deposito, bunga obligasi, dividen dan sebagainya sedangkan keuntungan selisih harga yang diterima karena adanya selisih antara harga jual dengan harga beli saham suatu instrumen. Menurut (Hartono, 2013) return dibagi menjadi realized return dan expected return. (Zubir, 2011) berpendapat sumber-sumber return saja ada dua, yaitu capital gain dan dividen yield. Capital gain adalah selisih antara harga jual dan harga beli saham per lembar dibagi dengan harga beli. Dividend yield merupakan deviden per lembar dibagi dengan harga beli saham per lembar. Faktor-faktor yang mempengaruhi return saham menurut (Samsul, 2015) ada dua, yaitu faktor makro dan faktor mikro. Faktor makro merupakan faktor yang berada di luar perusahaan (eksternal) yaitu faktor makro ekonomi yang meliputi tingkat bunga umum domestik, tingkat inflasi, kurs valuta asing dan kondisi ekonomi internasional serta faktor makro non ekonomi yang meliputi peristiwa politik di luar negeri, peperangan, demonstrasi masa dan kasus lingkungan hidup. Faktor mikro merupakan faktor yang berada di dalam perusahaan (internal) itu sendiri seperti return on assets, debt to equity ratio, price to book value, price earning ratio dan sebagainya di mana secara sistematis rumusnya :

$$
\mathrm{Rt}=(\mathrm{Pt}-\mathrm{Pt}-1) / \mathrm{Pt}-1
$$


$\mathrm{Rt}=$ return saham pada periode $\mathrm{t}$

$\mathrm{Pt}=$ harga saham pada periode $\mathrm{t}$

Pt-1 = harga saham pada periode Pt-1

Pengertian Return on Asset (ROA)

Return on Assets menurut (Kasmir, 2013) adalah rasio yang menunjukan hasil (return) atas jumlah aktiva yang digunakan dalam perusahaan. Return on Assets memberikan ukuran yang lebih baik atas profitabilitas perusahaan karena menunjukan efektivitas manajemen dalam menggunakan aktiva untuk memperoleh pendapatan. ROA berkaitan dengan aktiva yang dimiliki oleh perusahaan dan laba yang diperoleh perusahaan, oleh karena itu ROA merupakan pengukuran terbaik jika ingin mengukur kinerja laba maupun aktiva perusahaan. Menurut
(Munawir, 2010) ROA juga dapat digunakan sebagai tolak ukur jika manajemen ingin mengevaluasi seberapa baik perusahaan telah memakai dananya, ini ditunjukan dengan semakin besar tingkat ROA yang diperoleh semakin besar juga tingkat keuntungan yang diperoleh perusahaan tersebut dan semakin baik juga posisi perusahaan tersebut dari segi penggunaan aset. Berdasarkan pengertian tersebut, semakin besar rasionya maka semakin efektif perusahaan tersebut dalam mengelola asetnya untuk menghasilkan jumlah laba bersih yang lebih besar.

$$
R O A=\frac{\text { Laba Bersih Setelah Pajak }}{\text { Total Asset }} \times 100 \%
$$

Pengertian Debt to Equity Ratio

(DER)

Debt to Equity Ratio (DER) menurut (Verawati Rika, 2014) adalah rasio yang dipakai sebagai alat untuk mengukur tingkat leverage dalam menggambarkan kemampuan perusahaan untuk memenuhi kewajiban jangka panjang yang menghubungkan antara total debt dengan total equitas. Pendapat lain menurut (Kasmir, 2013) debt to equity ratio (DER) adalah rasio utang yang digunakan sebagai alat 
mengukur perbandingan antara total utang dan total aktiva. Artinya seberapa besar aktiva perusahaan dibiayai oleh utang dan seberapa besar utang perusahaan berpengaruh terhadap pengelolaan aktiva. (Harahap, 2010) mengatakan rasio debt to equity ratio mencerminkan sampai sejauh mana modal pemilik dapat menutupi utangnya kepada pihak luar. Semakin kecil rasionya maka semakin bagus. Rumus debt to equity ratio adalah :

\section{Debt to Equity Ratio $=\frac{\text { Total Liabilities }}{\text { Ekuitas }}$}

Pengertian Price to Book Value (PBV)

(Verawati Rika, 2014) menyatakan market to book atau price to book value adalah rasio pasar yang dipakai sebagai alat untuk mengukur kinerja harga pasar saham terhadap nilai buku saham. Harga pasar tersebut merupakan harga saham di pasar bursa pada waktu tertentu yang dipengaruhi oleh permintaan dan juga penawaran saham yang bersangkutan di pasar bursa. Price to book value merupakan perbandingan atau perhitungan antara market value dengan book value saham. PBV ini merupakan suatu nilai yang digunakan untuk membandingkan apakah saham lebih murah atau apakah lebih mahal dibandingkan dengan saham yang lain. Selain itu, price to book value mencerminkan keadaan market value keuangan terhadap manajemen organisasi dari perusahaan yang sedang berjalan yang menganut prinsip going concern. Rumus Book Value secara sistematis yang ditulis oleh (Verawati Rika, 2014) adalah sebagai berikut :

$$
\text { Book Value }=\frac{\text { I otal Equicy }}{\text { Jumlah Saham yang Beredar }}
$$

(Verawati Rika, 2014) menyatakan jika price to book value yang sehubungan dengan hal tersebut yaitu sebagai alat untuk mengukur kinerja harga pasar saham terhadap nilai bukunya sehingga rumus untuk price to book value adalah sebagai berikut: 


$$
\text { Price To Book Value }=\frac{\text { Harga Pasar Saham }}{\text { Nilai Buku Per Lembar Saham }}
$$

Hipotesis

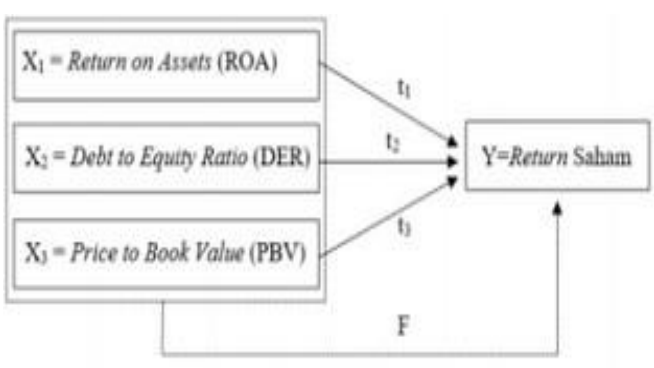

Keterangan:

Pengaruh $\mathrm{X}_{1}, \mathrm{X}_{2}, \mathrm{X}_{3}$ secara parsial terhadap return saham

Pengaruh $\mathrm{X}_{1}, \mathrm{X}_{2}, \mathrm{X}_{3}$ secara simultan terhadap return saham

$\mathrm{H}_{1}$ : Terdapat pengaruh positif dan signifikan return on assets terhadap return saham pada perusahaan LQ45 yang terdaftar di Bursa Efek Indonesia periode 2016-2018.

$\mathrm{H}_{2}$ : Terdapat pengaruh positif dan signifikan Debt to equity ratio terhadap return saham pada perusahaan LQ45 yang terdaftar di

\section{METODOLOGI PENELITIAN}

Dalam penelitian ini penulis menggunakan metode kuantitatif dengan pendekatan asosiatif dan deskriptif dan digunakan juga metode analisis deskriptif untuk
Bursa Efek Indonesia periode 20162018.

$\mathrm{H}_{3}$ : Terdapat pengaruh positif dan signifikan price to book value terhadap return saham pada perusahaan LQ45 yang terdaftar di Bursa Efek Indonesia periode 20162018 .

$\mathrm{H}_{4}$ : Terdapat pengaruh yang signifikan return on assets, debt to equity ratio, dan price to book value secara simultan terhadap return saham pada perusahaan LQ45 yang terdaftar di Bursa Efek Indonesia periode 2016 - 2018.

menunjukan nilai maksimum, nilai minimum, mean (nilai rata - rata) dan standar deviasi dari masingmasing variabel yang digunakan dalam penelitian ini, tujuannya adalah untuk menggambarkan data 
yang telah terkumpul sebagaimana adanya tanpa bermaksud membuat kesimpulan yang berlaku untuk umum. Penelitian ini menggunakan data sekunder dengan mengunduh langsung melalui website resmi Bursa Efek Indonesia yaitu www.idx.co.id.

Tabel 2 Daftar Sampel Perusahaan LQ45

\begin{tabular}{|c|c|c|}
\hline No. & Kode & Nama Perusahaan \\
\hline 1 & ADHI & Adhi Karya (Persero) Tbk \\
\hline 2 & ADRO & Adaro Energy Tbk \\
\hline 3 & AKRA & AKR Corporindo Tbk \\
\hline 4 & ANTM & Aneka Tambang Tbk. \\
\hline 5 & ASII & Astra International Tbk \\
\hline 6 & BBCA & Bank Central Asia Tbk \\
\hline 7 & BBNI & Bank Negara Indonesia \\
\hline 8 & BBRI & Bank Rakyat Indonesia (Persero) Tbk \\
\hline 9 & BBTN & Bank Tabungan Negara (Persero) Tbk \\
\hline 10 & BMRI & Bank Mandiri (Persero) Tbk. \\
\hline 11 & BSDE & Bumi Serpong Damai Tbk. \\
\hline 12 & GGRM & Gudang Garam Tbk. \\
\hline 13 & HMSP & HM Sampoerna Tbk. \\
\hline 14 & ICBP & Indofood CBP Sukses Makmur Tbk. \\
\hline 15 & INCO & Vale Indonesia Tbk. \\
\hline 16 & INDF & Indofood Sukses Makmur Tbk. \\
\hline 17 & INTP & Indocement Tunggal Prakasa Tbk. \\
\hline 18 & JSMR & Jasa Marga (Persero) Tbk. \\
\hline 19 & KLBF & Kalbe Farma Tbk \\
\hline 20 & LPKR & Lipo Karawaci Tbk. \\
\hline 21 & LPPF & Matahari Department Store Tbk. \\
\hline 22 & MNCN & Media Nusantara Citra Tbk. \\
\hline 23 & PGAS & Perusahaan Gas Negara (Persero) Tbk \\
\hline 24 & PTBA & $\begin{array}{c}\text { Tambang Batubara Bukit Asam (Persero) } \\
\text { Tbk }\end{array}$ \\
\hline 25 & PTPP & PP (Persero) Tbk. \\
\hline 26 & SCMA & Surya Citra Media Tbk. \\
\hline 27 & SMGR & Semen Indonesia (Persero) Tbk. \\
\hline 28 & SRIL & Sri Rejeki Isman Tbk. \\
\hline 29 & SSMS & Sawit Sumbermas Sarana Tbk. \\
\hline 30 & TLKM & Telekomunikasi Indonesia (Persero) Tbk. \\
\hline 31 & UNTR & United Tractors Tbk. [S] (Wholesale \\
\hline 32 & UNVR & Unilever Indonesia Tbk. \\
\hline 33 & WIKA & WIKA Wijaya Karya (Persero) Tbk. \\
\hline 34 & WSKT & WSKT Waskita Karya (Persero) Tbk. \\
\hline
\end{tabular}


Pengaruh Return on Assets, Debt to Equity Ratio dan Price to Book Value Terhadap Return Saham Perusahaan LQ45 Terdaftar di Bursa Efek Indonesia Periode 2016-2018

\section{HASIL DAN PEMBAHASAN}

Tabel 3 Statistik Deskriptif Data Penelitian

\begin{tabular}{lrrrrrr}
\multicolumn{7}{c}{ Descriptive Statistics } \\
& N & Minimum & Maximum & Mean & Std. Deviation \\
\hline ROA $(\%)$ & 102 & -70 & 46.66 & 9.2667 & 9.89907 \\
\hline DER $(X)$ & 102 & 15 & 11.06 & 1.9034 & 2.21813 \\
\hline PBV $(X)$ & 102 & 22 & 82.44 & 4.7538 & 10.30234 \\
\hline RETURN SAHAM $(\%)$ & 102 & -9.09 & 4.97 & -.1993 & 1.90522 \\
\hline Valid N (listwise) & 102 & & & & \\
\hline
\end{tabular}

Tabel 4 Data Hasil Penelitian

\begin{tabular}{|c|c|c|c|c|c|c|c|c|c|c|}
\hline \multirow{2}{*}{ No. } & \multirow{2}{*}{ PERUSAKAAN LQAS } & \multicolumn{3}{|c|}{ ROA (\%) } & \multicolumn{3}{|c|}{$\operatorname{DER}(x)$} & \multicolumn{3}{|c|}{$\operatorname{PBV}(x)$} \\
\hline & & 2016 & 2017 & 2018 & 2016 & 2017 & 2018 & 2016 & 2017 & 2018 \\
\hline 1 & AOHI & 1.57 & 1.82 & 2.14 & 2.69 & 3.83 & 3,80 & 1.43 & 1,14 & 0,92 \\
\hline 2 & ADRO & 5.22 & 7.87 & 6.76 & 0,72 & 0.67 & 0,64 & 1,18 & 1,07 & 0,60 \\
\hline 3 & AXRAA & 6,61 & 7.75 & 8,01 & 0.96 & 0.86 & 1.01 & 3,06 & 2.82 & 1.80 \\
\hline 4 & ANTM & 0,22 & 0,45 & 2,63 & 0,63 & 0.62 & 0.69 & 1,17 & 0.81 & 0,96 \\
\hline 5 & ASII & 6,99 & 7,84 & 7,94 & 0,87 & 0,89 & 0,98 & 2,54 & 2,15 & 1,98 \\
\hline 6 & $B B C A$ & 3.05 & 3,11 & 3,13 & 4,97 & 4,68 & 4,40 & 3,49 & 4,11 & 4,46 \\
\hline 7 & BBNI & 1,89 & 1.94 & 1.87 & 5,52 & 5,79 & 6,08 & 1,19 & 1,83 & 1,58 \\
\hline 8 & BBRI & 2,61 & 2,58 & 2,50 & 5,84 & 5,73 & 5,92 & 2,04 & 2,68 & 2,57 \\
\hline 9 & BQT⿰亻丨 & 1,22 & 1,16 & 0,92 & 10,20 & 10,34 & 11,06 & 1,02 & 1,75 & 1,16 \\
\hline 10 & BMRI & 1,41 & 1,91 & 2,15 & 5,38 & 5,22 & 5,09 & 1,77 & 2,20 & 1,95 \\
\hline 11 & BSDE & 5,32 & 11,29 & 3,27 & 0,57 & 0,57 & 0,72 & 1,44 & 1,12 & 0,81 \\
\hline 12 & GGRM & 10,60 & 11,62 & 11,28 & 0,59 & 0.58 & 0,53 & 3,27 & 4,04 & 3,75 \\
\hline 13 & HMSP & 30,02 & 29,37 & 29,05 & 0.24 & 0,26 & 0.32 & 14.51 & 16,13 & 13,74 \\
\hline 14 & ICBP & 12.56 & 11.21 & 13,56 & 0,56 & 0,56 & 0.51 & 5.61 & 5,11 & 5,56 \\
\hline 15 & INCO & 0.09 & -0.70 & 2.75 & 0.21 & 0.20 & 0.17 & 1.18 & 1.17 & 1.16 \\
\hline 16 & INDF & 6,41 & 5.85 & 5,14 & 0.87 & 0,88 & 0.93 & 1.55 & 1,43 & 1.35 \\
\hline 17 & INTP & 12.84 & 6,44 & 4,12 & 0.15 & 0,18 & 0,16 & 2.23 & 3,29 & 3.01 \\
\hline 18 & ISMR & 3.37 & 2.64 & 2,47 & 2.27 & 3,31 & 3.08 & 2.26 & 2,53 & 1.65 \\
\hline 19 & KLBF & 15,44 & 14,76 & 13,76 & 0,22 & 0,20 & 0,19 & 6,01 & 5,97 & 4,89 \\
\hline 20 & LPKR & 2,69 & 1.51 & 3,47 & 1.07 & 0,90 & 0,96 & 0,76 & 0,43 & 0,22 \\
\hline 21 & LPPF & 41.57 & 35,14 & 21,79 & 1,62 & 1,33 & 1,77 & 30,03 & 12,53 & 6,57 \\
\hline 22. & MNCN & 10,41 & 10,41 & 9,83 & 0,50 & 0,54 & 0,54 & 2,57 & 1,90 & 0,94 \\
\hline 23 & PGAS & 4,52 & 2.35 & 4,59 & 1,16 & 0,97 & 1,48 & 1,62 & 0,98 & 1,04 \\
\hline 24 & PTBA & 10,90 & 20,68 & 21,19 & 0,76 & 0,59 & 0,49 & 3,00 & 2,05 & 3,32 \\
\hline 25 & PTPP & 3,69 & 4,13 & 3,73 & 1,89 & 1,93 & 2,22 & 4,12 & 1,15 & 0,73 \\
\hline 26 & $\mathrm{SCMA}$ & 31,35 & 24,47 & 24,03 & 0,30 & 0.22 & 0,20 & 9,80 & 7,76 & 5,38 \\
\hline 27 & SMGR & 10,25 & 4,17 & 6.03 & 0,45 & 0,61 & 0,56 & 1,91 & 1,93 & 2,15 \\
\hline 28 & SRIL & 6.27 & 6,75 & 6,20 & 1.86 & 1,70 & 1,64 & 1,07 & 1,30 & 0,98 \\
\hline 29 & SSMS & 8.10 & 8.10 & 1,10 & 1.05 & 1,34 & 1,78 & 4.19 & 3.53 & 2,74 \\
\hline 30 & TUKM & 16,24 & 16,48 & 13,08 & 0,70 & 0,77 & 0,76 & 4,23 & 3,99 & 3.50 \\
\hline 31 & UNTR & 798 & 9.33 & 9.89 & 0,50 & 0,73 & 1.04 & 1.97 & 2.78 & 1.87 \\
\hline 32 & UNVR & 38,16 & 37.05 & 46.66 & 2.56 & 2.65 & 1.58 & 46.67 & 82,44 & 38.62 \\
\hline 33 & WIKA & 3.69 & 2.97 & 3.50 & 1.49 & 2,12 & 2,44 & 3,71 & 0.95 & 0.96 \\
\hline 34 & WSKT & 2.95 & 4.29 & 3.71 & 2.66 & 3,30 & 3.31 & 2,14 & 1,32 & 0,84 \\
\hline
\end{tabular}

Sumber : Data yang diolah (2019)

Tabel 5 Hasil Analisis Regresi Linier Berganda dan Uji t

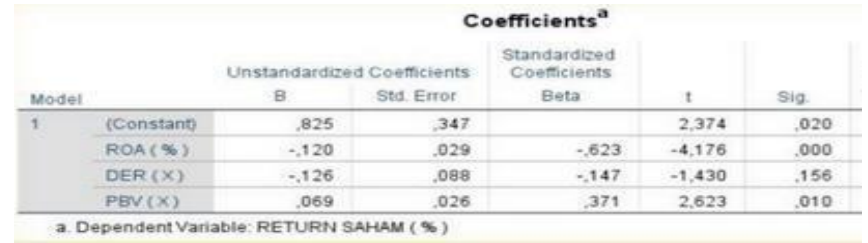

Sumber : Data yang diolah (2019) 
Tabel 6 Hasil Uji Koefisien Determinasi

\begin{tabular}{|c|c|c|c|c|c|}
\hline \multicolumn{6}{|c|}{ Model Summary } \\
\hline Model & $R$ & R Square & $\begin{array}{c}\text { Adjusted R } \\
\text { Square }\end{array}$ & $\begin{array}{l}\text { Std. Error of } \\
\text { the Estimate }\end{array}$ & $\begin{array}{l}\text { Durbin- } \\
\text { Watson }\end{array}$ \\
\hline 1 & $886^{3}$ & .784 &, 761 & 1,77579 & 1,763 \\
\hline
\end{tabular}

Sumber : Data yang diolah (2019)

Tabel 7 Hasil Uji F

\begin{tabular}{|c|c|c|c|c|c|c|}
\hline \multicolumn{7}{|c|}{ ANOVA $^{a}$} \\
\hline Model & & $\begin{array}{l}\text { Sum of } \\
\text { Squares }\end{array}$ & df & Mean Square & $\mathrm{F}$ & Sig. \\
\hline \multirow[t]{3}{*}{1} & Regression & 57,581 & 3 & 19,194 & 6,087 &, $001^{b}$ \\
\hline & Residual & 309,035 & 98 & 3,153 & & \\
\hline & Total & 366,616 & 101 & & & \\
\hline
\end{tabular}

Sumber : Data yang diolah (2019)

Deskripsi statistik variabel penelitian berdasarkan tabel 3 dapat dijelaskan sebagai berikut :

\section{Return on Assets (ROA)}

Return on Assets memiliki nilai minimum sebesar $-0,70$, nilai maksimum sebesar 46,66, mean sebesar 9,2667 dan standar deviasi 9,89907. Nilai ROA maksimum dicapai oleh PT Unilever Indonesia Tbk. Tahun 2018 yaitu 46,66, sedangkan ROA minimum dicapai oleh PT Vale Indonesia Tbk. Tahun 2017 sebesar $-0,70$.
2. Debt to Equity Ratio (DER) debt to equity ratio memiliki nilai minimum sebesar 0,15 , nilai maksimum sebesar 11,06, mean sebesar 1,9034 dan standar deviasi 2,21813. Nilai DER maksimum dicapai oleh PT Bank Tabungan Negara (Persero) Tbk. Tahun 2018 yaitu 11,06, sedangkan DER minimum dicapai oleh PT Indocement Tunggal Prakasa Tbk. Tahun 2016 sebesar 0,15.

3. Price to book value (PBV) price to book value memiliki nilai minimum sebesar 0,22 , nilai maksimum 
sebesar 82,44, mean sebesar 4,7538 dan standar deviasi 10,30234 . Nilai PBV maksimum dicapai oleh PT Unilever Indonesia Tbk. Tahun 2017 yaitu 82,44, sedangkan PBV minimum dicapai oleh PT Lippo Karawaci Tbk. Tahun 2018 sebesar 0,22 .

\section{Return Saham}

Return saham memiliki nilai minimum sebesar $-9,09$, nilai maksimum sebesar 4,97, mean sebesar -0,1993 dan standar deviasi 1,90522. Nilai return saham maksimum dicapai oleh PT Sri Rejeki Isman Tbk. Tahun 2017 yaitu 4,97 sedangkan return saham minimum dicapai oleh PT Matahari Department Store Tbk. Tahun 2017 sebesar $-9,09$.

Pengaruh Return on Assets, Debt to Equity Ratio dan Price to Book Value terhadap Return Saham Secara Parsial Return on Assets (ROA).

Pengaruh return on assets terhadap return saham pada perusahaan LQ45 yang terdaftar di Bursa Efek Indonesia periode 2016-2018. Hasil penelitian ini menunjukan bahwa return on assets berpengaruh negatif dan signifikan terhadap return saham pada perusahaan LQ45 yang terdaftar di Bursa Efek Indonesia periode 2016 - 2018. Dalam penelitian ini ROA berpengaruh negatif yang menunjukan ketika ROA turun tetapi return saham naik, ketika ROA naik tetapi return saham turun. Hal tersebut disebabkan karena sebelum laporan keuangan perusahaan terbit adanya informasi yang beredar di pasar mengenai ROA perusahaan (adanya informasi yang bocor di pasar) sehingga investor merespon dan menganalisis lebih awal informasi tersebut yang menyebabkan terbentuknya harga pasar yang baru.

\section{Debt to Equity Ratio (DER)}

Pengaruh debt to equity ratio terhadap return saham pada perusahaan LQ45 yang terdaftar di Bursa Efek Indonesia periode 20162018. Hasil penelitian ini menunjukan bahwa debt to equity ratio tidak berpengaruh terhadap return saham pada perusahaan LQ45 yang terdaftar di Bursa Efek Indonesia periode 2016 - 2018 . Tingkat DER yang tinggi menunjukkan bahwa perusahaan 
banyak didanai oleh hutang daripada modal sendiri. Semakin tinggi DER maka semakin tinggi juga resiko tidak mampu membayar hutang. Pada periode penelitian ini nilai rata

- rata (mean) DER adalah 1,9034 kali dan terlihat DER yang diatas nilai rata - rata tersebut masih dapat menghasilkan return saham yang diatas rata - rata penelitian ini yaitu 0,1993\%. Misalnya pada perusahaanperusahaan bank yaitu BBCA, BBRI, BBTN dan BMRI. Hal tersebut mencerminkan DER yang tinggi belum tentu return saham akan rendah atau turun maka investor tidak menilai DER sebagai faktor pengambilan keputusan investasi pada periode penelitian ini. Untuk Perusahaan yang memiliki DER yang besar atau diatas rata-rata DER pada penelitian ini agar tetap menjaga kepercayaan investor maka harus membayar cicilan dan bunga yang lancar sehingga kondisi keuangan perusahaan tetap stabil.

\section{Price to Book Value (PBV)}

Pengaruh price to book value terhadap return saham pada perusahaan LQ45 yang terdaftar di Bursa Efek Indonesia periode 2016 -
2018. Hasil penelitian ini menunjukan bahwa price to book value berpengaruh positif dan signifikan terhadap return saham pada perusahaan LQ45 yang terdaftar di Bursa Efek Indonesia periode 2016 - 2018. PBV berpengaruh positif mencerminkan semakin tinggi PBV maka semakin tinggi juga return saham. Pada periode ini investor menilai perusahaan yang PBV nya naik berarti kinerja keuangannya ikut naik, sehingga banyak permintaan yang menyebabkan harga saham naik dan mempengaruhi kenaikan return saham. Perusahaan harus tetap menjaga penilaian yang bagus ini kedepannya agar semakin banyak menarik investor untuk berinvestasi. Pengaruh return on assets, debt to equity ratio dan price to book value terhadap return saham secara simultan pengaruh return on assets, debt to equity ratio dan price to book value secara simultan terhadap return saham pada perusahaan LQ45 yang terdaftar di Bursa Efek Indonesia periode 2016 - 2018. Dalam penelitian ini ROA berpengaruh negatif dan PBV berpengaruh positif terhadap return 
saham. DER secara parsial tidak berpengaruh terhadap return saham akan tetapi secara bersama-sama atau simultan ketiga variabel ini ternyata mempengaruhi return saham. Hal ini dibuktikan dengan tingkat signifikan uji $\mathrm{F}$ lebih kecil dari 0,05 yaitu sebesar 0,001. Melihat hal tersebut maka ketiga variabel ini masih bisa dipakai sebagai keputusan berinvestasi kedepannya, sehingga perusahaan pun harus tetap memperhatikannya. Besarnya

\section{SIMPULAN}

Simpulan dalam penelitian ini terdapat pengaruh negatif dan signifikan return on assets terhadap return saham. Tidak terdapat pengaruh positif dan signifikan debt to equity ratio terhadap return saham. Terdapat pengaruh positif dan signifikan price to book value terhadap return saham. Terdapat pengaruh yang signifikan return on assets, debt to equity ratio, dan price to book value secara simultan terhadap return saham. Koefisien determinasi $\left(\mathrm{R}_{2}\right)$ sebesar $78,4 \%$ dan sisanya $21,6 \%$ dipengaruhi oleh faktor - faktor lain yang tidak dimasukan dalam model regresi pengaruh return on assets, debt to equity ratio dan price to book value terhadap return saham Berdasarkan tabel 6 besarnya pengaruh variabel independen yaitu return on assets, debt to equity ratio dan price to book value terhadap variabel dependen yaitu return saham sebesar $78,4 \%$ dan sisanya $21,6 \%$ dipengaruhi oleh faktor-faktor lain yang tidak dimasukan dalam model regresi penelitian ini.

penelitian ini. Nilai $\mathrm{R}_{2}$ sebesar $78,4 \%$ menunjukan kemampuan variabel independen dalam menjelaskan variabel dependen. Saran bagi investor dan calon investor agar ROA dan PBV dapat digunakan sebagai pertimbangan dalam pengambilan keputusan investasi karena dalam penelitian ini ROA dan PBV berpengaruh signifikan terhadap return saham. Penelitian selanjutnya diharapkan dapat menambah variabel-variabel lainnya selain ROA, DER dan PBV, selain itu periode penelitian ini adalah tiga tahun, sangat diharapkan jika peneliti selanjutnya untuk menambah periode 
penelitian agar hasil yang lebih

\section{DAFTAR PUSTAKA}

Fadhilah Fitri. (2018). Pengaruh Total Asset Turnover, Current Ratio, Debit To Equity Ratio, Dan Return On Equity Terhadap Return Saham Pada Perusahaan Manufaktur Di Bursa Efek Indonesia (Bei).

Fahmi, I. (2013). Analisis Laporan Keuangan. Alfabeta.

Fahmi, I. (2015). Pengantar Manajemen Keuangan Teori dan Soal Jawab. Alfabeta.

Hadi. (2013). Pasar Modal Acuan Teoritis dan Praktis Investasi di Instrumen Keuangan Pasar Modal. Graha Ilmu.

Hadi, S. (2012). Pengaruh return on equity (ROE) dan return on assets (ROA) terhadap return saham melalui earning per share (EPS): Studi pada perusahaan manufaktur tahun 2009-2011.

Harahap, S. (2010). Analisis Kritis Atas Laporan Keuangan. Rajawali Pers.

Hartono, J. (2013). Teori Portofolio dan Analisis Investasi (8th ed.). BPFE.

Hartono, J. (2016). Teori Portofolio dan Analisis Investasi (10th ed.). BPFE.

Ikatan Akuntansi Indonesia. (2012). Standar Akuntansi Keuangan. Salemba Empat.

Jumingan. (2011). Analisis Laporan Keuangan.

Kasmir. (2013). Analisis Laporan Keuangan. Rajawali Pers.

Munawir. (2010). Analisa Laporan Keuangan. liberty.

Nasrullah, M. F. (2011). Pengaruh Return On Asset (ROA), Return akurat mengenai return saham.

On Equity (ROE), dn Equity to Asset Rati (EAR) terhadap return saham pada perusahaan LQ45 periode 2006-2009.

Prihantini, R. (2009). Analisis

Pengaruh Inflasi,Nilai Tukar,ROA,DER dan CR Terhadap Return Saham Perusahaan Real Estate dan Property Terdaftar di BEI Periode 2003-2006. Jurnal Bisnis Strategi, 18(2). https://doi.org/https://doi.org/10 $.14710 /$ jbs.18.2.99-117

Samsul, M. (2015). Pasar Modal dan Manajemen Portofolio. Erlangga.

Sudrajat, A. (2015). Pengaruh Roe, Der, Eps, Reputasi Underwriter, Dan Reputasi Auditor Terhadap Tingkat Underpricing Pada Perusahaan Sektor Property Dan Real Estate Yang Melakukan Initial Public Offering Di Bei Tahun 2007-2015.

Verawati Rika. (2014). FaktorFaktor Penentu Yang Mempengaruhi Return Saham Perusahaan Manufaktur Yang Terdaftar Di Bursa Efek Indonesia (Bei) Periode 20082013.

Widoatmodjo, S. (2012). Cara Sehat Investasi di Pasar Modal. PT. Jurnalindo Aksara Grafika.

Zubir, Z. (2011). Manajemen Portofolio (Penerapannya dalam Investasi Saham). Jakarta: Salemba Empat. Salemba Empat. 